\title{
A water footprint assessment of a pair of jeans: the influence of agricultural policies on the sustainability of consumer products
}

\author{
Daniel Chico ， Maite M. Aldaya , Alberto Garrido
}

\begin{abstract}
A B S T R A C T
This study reports the results of a water footprint (WF) assessment of five types of textiles commonly used for the production of jeans, including two different fibres (cotton and Lyocell fibre) and five corresponding production methods for spinning, dyeing and weaving. The results show that the fibre production is the stage with the highest water consumption, being cotton production particularly relevant. Therefore, the study pays particular attention to the water footprint of cotton production and analyses the effects of external factors influencing the water footprint of a product, in this case, the incentives provided by the EU Common Agricultural Policy (CAP), and the relevance of agricultural practices to the water footprint of a product is emphasised. An extensification of the crop production led to higher WF per unit, but a lower overall pressure on the basins' water resources. This study performs a sustainability assessment of the estimated cotton WFs with the water scarcity index, as proposed by Hoekstra et al. (2011), and shows their variations in different years as a result of different water consumption by crops in the rest of the river basin. In our case, we applied the assessment to the Guadalquivir, Guadalete and Barbate river basins, three semi-arid rivers in South Spain. Because they are found to be relevant, the available water stored in dams and the outflow are also incorporated as reference points for the sustainability assessment. The study concludes that, in the case of Spanish cotton production, the situation of the basin and the policy impact are more relevant for the status of the basin's water resources than the actual WF of cotton production. Therefore, strategies aimed at reducing the impact of the water footprint of a product need to analyse both the WF along the value chain and within the local context.
\end{abstract}

\section{Introduction}

It is increasingly recognised that indirect water users, such as consumers, trading, and manufacturing companies, are relevant factors in the path toward a greener economy. More companies are undertaking initiatives to gain a better understanding of their water-related risks along their value chains. Nevertheless, traditional corporate water accounting often fails to address water use and management in the supply chain. Several tools have recently been developed to overcome these limitations: some are accounting tools for water use and operational risk, whereas other approaches aim to introduce the impacts of consumption (UNEP/SETAC) or to promote a deeper engagement in resource management (Alliance for Water Stewardship, 2012). A reference to most of these tools can be found in the web page of the CEO Water Mandate (CEOWM, 2012). All these initiatives present strengths and weaknesses (UNEP, 2011), and many are still under development (Bayart et al., 2010). It is clear, however, that these tools respond to different views and perspectives (Schornagel et al., 2012).

One such tool is a water footprint assessment. As an indicator, the water footprint (WF) measures the appropriation of water resources by human activity by evaluating water consumption and the impact on water quality. However, the results of water footprint accounting are not completely informative with regard to local sustainability because WF provides only an evaluation of water abstraction or utilisation, with no reference to the local or regional conditions under which it was performed Jeswani and Azapagic, 2011). To this end, the 'Water Footprint Assessment Manual' (Hoekstra et al., 2011) recommends that the performance of a sustainability assessment be thoroughly checked. This entails the 
comparison of the water footprint being analysed (product, consumer, or region) with the local water availability, which is obtained from the comparison of the available water resources with the total water footprint of the basin. The available water resources would be the natural runoff minus the environmental flow requirements.

To better assess the impacts and allow comparability among different WFs, some authors have suggested that water footprints be weighted by a scarcity factor (Ridoutt et al.,2011), in accordance with Life Cycle Assessment (LCA) methodology (Koehler, 2008). Several indexes have been proposed to this end. Pfister et al. (2009) proposed three areas of protection, human health, ecosystem quality, and resources, and discussed a global characterisation and the damage factors for watershed-level consumptive water use, applying them to global cotton production. Pfister et al. (2009) and Milà i Canals et al. (2009) proposed two impact pathways for water use and corresponding characterisation factors, and, based on the water stress index of Pfister et al. (2009), Ridoutt and Pfister (2012) developed a characterisation factor for water footprint assessments. The application of different methodologies for impact assessment leads to different results, necessitating a more standardised methodology (Jeswani and Azapagic, 2011). Page et al. (2012) recognises the need for an improvement of the impact assessment at the endpoint level. Measuring water scarcity is a complex process that depends on the spatial and temporal scales of the analysis (Rijsberman, 2006). Recently, Jefferies et al. (2012) considered the synergy of LCA and WFA methodologies and identified the differences in scope and focus of both methods. The blue water footprint may serve in the inventory phase of the LCA assessment, though green and grey WFs are usually recommended for accounting in other impact categories (Milá i Canals, 2009; Pfister et al., 2009). Several papers have recently applied the different methodologies for water footprint accounting and impact assessment. Jeswani and Azapagic (2011) applied different methodologies to the case of corn-based ethanol in 12 countries. Jefferies et al. (2012) studied two Unilever products, margarine and tea, from cradle to gate. Zonderland-Thomassen and Ledgard (2012) analysed two different dairy farming systems in New Zealand. Herath et al. (2013a, 2013b) applied a water balance approach to two wine production systems in New Zealand, obtaining negative water footprints for the grape growing stage. These articles agree that the LCA and the WF communities share the same challenges with regard to the assessment of products. Assessing the environmental impacts of water use, in a comprehensive, robust way is a complex task. There is a balance to be achieved between spatial detail of the impact assessment, which greatly increases accuracy but is highly data demanding, and the applicability of the method at larger scales, which is needed for methodologies trying to asses worldwide supply chains. Potential synergies exist because they rely on the same data for water accounting and impact assessment and would benefit from further collaboration and the joint development of methods.

One of the strengths of WF is the transparency of the results, as water consumption estimates may be disaggregated at the lowest possible level, affording more flexibility for evaluating the impacts of water consumption spatially and temporally. Indeed, one of the issues that LCA is improving in its impact assessment phase is the temporal and spatial definition of the characterisation factors, which are still not completely and satisfactorily developed (Jeswani and Azapagic, 2011). Nonetheless, the broad scope of LCA avoids problem-shifting (Cucek et al., 2012).

Several initiatives have catalysed significant progress for achieving more sustainable corporate water management, as in the case of the apparel sector. For example, the Better Cotton Initiative $(\mathrm{BCl}, 2012)$ is a joint project of relevant international companies of this sector with NGOS (WWF) and local organisations to promote the best farming practices for cotton growers in Brazil, Pakistan, India, and Mali. In addition to water, these practices are also focused on integrated pest management, working conditions, and soil conservation. The Sustainable Apparel Coalition is a joint effort of global companies for the development of a tool to measure the social and environmental performance of the products (SAC, 2012). Examples of certifications by third parties are the labels OEKOTEX Standard from International Association for Research and Testing in the Field of Textile Ecology, "Blue Sign" from Blue Sign AG, "Made in Green" by Aitex, and "Eco-label" from the European Union Commission, this last being applicable to other non-textile products. Muthu et al. (2012) have proposed an Ecological Sustainability Index specific for textile fibres, with 9 impact categories and a scoring system, indicating organic cotton as being a more environmentally friendly fibre than other natural and, in particular, man-made fibres. However, this approach is heavily dependent on the weighting factors chosen for each impact category.

Very few studies have been devoted to analyse the water footprint of cotton textiles. Mekonnen and Hoekstra (2010) reported that cotton accounts for $3.14 \%$ of the world's total water footprint. The authors estimated that the global average water footprint of cotton lint is 5163,2955 , and $966 \mathrm{~m}^{3} / \mathrm{t}$ for green, blue, and grey water, respectively; this average ranges from 5020,0 , and $1065 \mathrm{~m}^{3} / \mathrm{t}$ in Minas Gerais, Brazil, to 34923, 0, and 2213 in Gambia (where production is based on green water) or 18,4886 , and $396 \mathrm{~m}^{3} / \mathrm{t}$ in Syrian Dar'a region to 272, 21737, and $267 \mathrm{~m}^{3} / \mathrm{t}$ in the Afghan Nimruz region (where production depends on blue water). In a previous article focused on cotton production, Chapagain et al. (2006) quantified the global cotton water footprint at $256 \mathrm{Gm}^{3} / \mathrm{y}$, with a global average of 4264,4242 , and $622 \mathrm{~m}^{3} / \mathrm{t}$ for green, blue, and grey water, respectively. Using the LCA approach, Pfister et al. (2009) quantified the global average of (blue) water consumptive use for cotton production at $8540 \mathrm{~m}^{3} / \mathrm{t}$ and proposed a methodology to account for water consumption and related impacts within LCA methodology.

The goal of this paper is to evaluate the water footprint of a consumer product, denim trousers (blue jeans), by examining different raw materials and production methods along the entire value chain. Many textile products, including jeans, are produced using different combinations of cotton fibres with other synthetic fibres, such as lyocell fibre, which is produced with cellulose from the timber of different tree species. Furthermore, jean trousers are manufactured following widely different and environmentally sensitive production methods. Our study includes five different fabrics made from cotton and Lyocell fibres. In particular, the study focuses on the example of cotton production in 3 river basins in southern Spain. To evaluate how sensitive our water assessment is to some important factors, this paper analyses how the influence of cotton prices and sectoral policies on the production methods impacts the sustainability of a specific consumer product. The drivers of these different production methods affect the result of the product's WF and, therefore, need to be taken into account in an evaluation of the WF of a product. The analysis of the sustainability of the critical points in the product's WF is performed in two ways: the monthly water stress index (WSI), as proposed in Hoekstra et al. (2012), is calculated using the local data; the results are then discussed with the local actual outflow data and available water storage in dams.

\section{Methodology}

Our study analyses the water footprint of a range of fabrics made in Spain, from the origin of the raw material to the garment cutting and production of the final piece. Four of these fabrics are made 
from cotton, whereas the fifth is composed of Lyocell fibre, a textile fibre obtained from wood cellulose. The methodology was based on the water footprint assessment developed in Hoekstra et al. (2011). The green, blue, and grey water footprints of the processes in the textile value chain were estimated from the wood and cotton production stage to the industrial processes. Fig. $1 \mathrm{a}$ and $\mathrm{b}$ detail the production phases, the type of water included in the calculation, and the type of data source used. The system boundaries excluded the WF of transport and electricity and that of the packaging and manufacture of minor inputs to production.

\subsection{Cotton production in Spain}

Spain and Greece are the only EU countries that produce cotton. Although cotton is not one of the main crops in Spain, it is relevant in the producing areas, which are traditionally concentrated in the middle and lower Guadalquivir river and the Guadalete and Barbate rivers (see the map in Fig. 2). In 2005, 2009, this production area represented approximately $15 \%$ and $8 \%$, respectively, of the total irrigated surface in the Guadalquivir basin, exceeding $30 \%$ in some municipalities. According to the River Basin District Management Plan, cotton is the most extended irrigated crop in the Guadalquivir basin after olive trees (RBDMP, DHG, 2012).

The cultivated area exceeded 100,000 ha in 1999 but decreased to 86,000 ha in 2005 and to a minimum of 52,639 ha in 2008 (MAGRAMA, 2012). There was a partial recovery in the cultivated surface during 2009-2011, to 66,500 ha in 2011, which was linked to a $62 \%$ rise in international prices with respect to the average

\section{a}
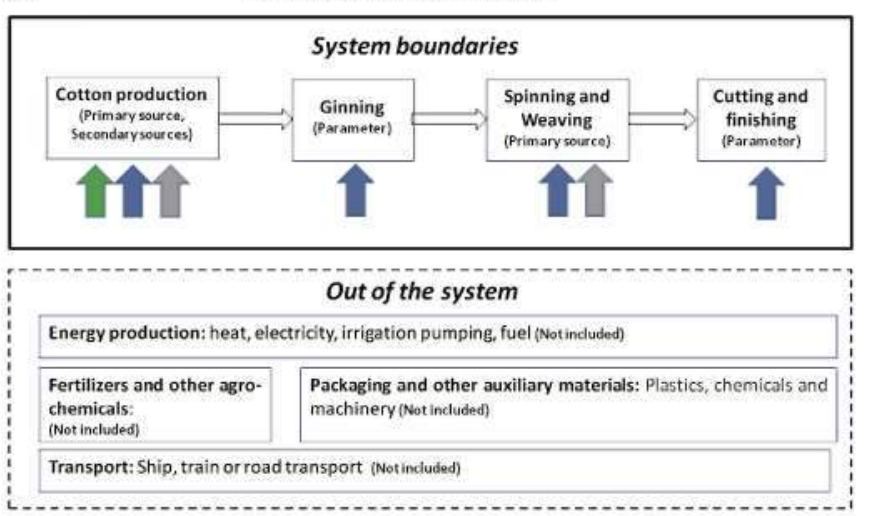

$\mathrm{b}$

Lyocell textile production Chain
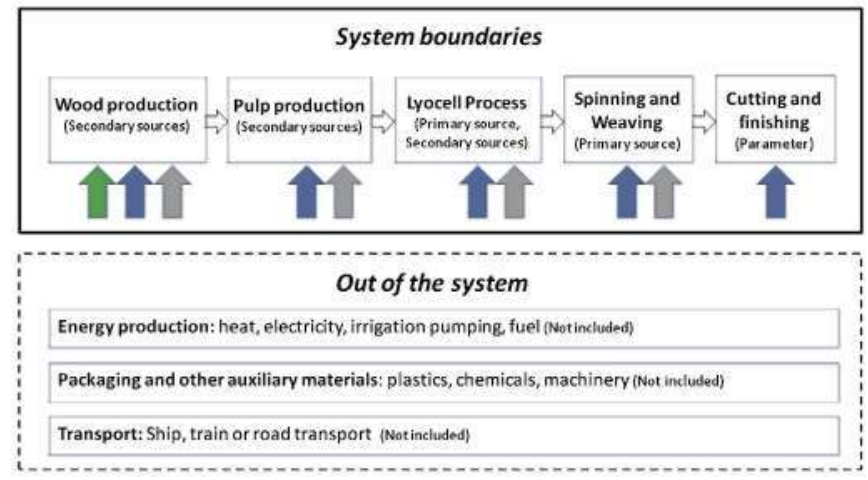

Fig. 1. a, b System boundaries of the production chain for cotton and Lyocell fibres, data source per process, and type of water taken into account per stage. The colour of the arrows indicate the type of water consumed at each point (green water, blue water, and grey water). (For interpretation of the references to colour in this figure legend, the reader is referred to the web version of this article.)
2007-2009 prices (Cotton Outlook, 2012). Irrigation is utilised in $93 \%$ of the planted cotton area in Spain, and different techniques, such as surface, drip, and sprinkler systems, are employed. Before 2006 , cotton was cultivated under plastic mulching, and a variety of agrochemicals were used, including fertilisers, phytosanitary products, and defoliants. Cotton is an intensive crop and generates significant socioeconomic revenues in terms of agricultural (Arriaza and Capellán, 2009) and associated income (JA, 2005).

Cotton production in Spain was affected by the partial decoupling $^{1}$ of the EU Common Agricultural Policy (CAP) from 2006 (Arriaza and Capellán, 2009). The decoupling reform introduced a change from receiving a payment per unit produced to receiving a basic payment per cultivated surface. Many farmers have either substituted cotton with other crops or have reduced the variable costs by reducing the number of irrigation applications (and water applied) and fertiliser and phytosanitary product usage. Integrated pest management practices spread to $75 \%$ of the surface area, which added $350 € /$ ha in payments and implied limitations on pesticide and fertiliser use (JA, 2007). Plastic-mulched area disappeared, rainfed areas increased from 5 to $10 \%$, and drip and furrow irrigation decreased (Granado et al., 2008). Although the average yields were $3500 \mathrm{~kg} / \mathrm{ha}$ in the 1995-2005 period, similar to the main producing countries worldwide, the yields decreased to 2500 and $1100 \mathrm{~kg} / \mathrm{ha}$ in 2007 and 2008 , respectively, particularly in Seville province, which accounts for more than $60 \%$ of the cultivated area (MAGRAMA, 2012). Furthermore, due to the few crop alternatives in the region, direct farm labour decreased an average of $43 \%$ (JA, 2007).

\subsection{Water accounting}

\subsubsection{Fibre production stage}

The green and blue water consumption of the cotton production stage in the Guadalquivir, Guadalete, and Barbate river basins was calculated with the software CROPWAT (FAO, 2009). The calculation was performed at the municipal level, distinguishing among the different irrigation techniques for 2005 and 2009. The monthly precipitation and potential evapotranspiration were obtained at the agricultural district level from the irrigation service of the regional government (SIAR, 2012). The crop evapotranspiration coefficient $\left(K_{c}\right)$ was obtained from Allen et al. (2006). Even though 2005 was a dry year, with precipitation approximately $50 \%$ of the average, it was declared a normal year in terms of drought risk because of the water stored in reservoirs (MAGRAMA, 2009). In contrast, 2009 was a normal year in terms of precipitation and drought risk (DHG, 2009 ), though only $50 \%$ of the crop irrigation water requirements were satisfied (García-Vila et al., 2008; Arriaza and Capellán, 2009). Data for the cotton crop area at the municipal level were obtained from the Spanish Ministry of Agriculture, Food and Environment (MAGRAMA, 2012). The yield and share of area per irrigation technique and province were obtained from the cotton production statistics of the Andalusian government (JA, 2008). The green and blue water footprint of the cotton production $\left(\mathrm{m}^{3} / \mathrm{t}\right)$ was calculated using the estimated green and blue water consumption and the yield per province and irrigation type (rainfed and surface, sprinkler, or drip irrigation).

Because the amount of fertilisation needed depends, among other factors, on the crop, soil, agricultural practices, and expected yield, we considered the impact of nitrogen fertilisation to estimate the grey water footprint of cotton production. The grey water

\footnotetext{
${ }^{1}$ Decoupling: Introduced by the 2003 reform of the EU common agricultural policy, decoupling is the removal of the link between the receipt of a direct payment and the production of a specific product Source: EC (2013).
} 


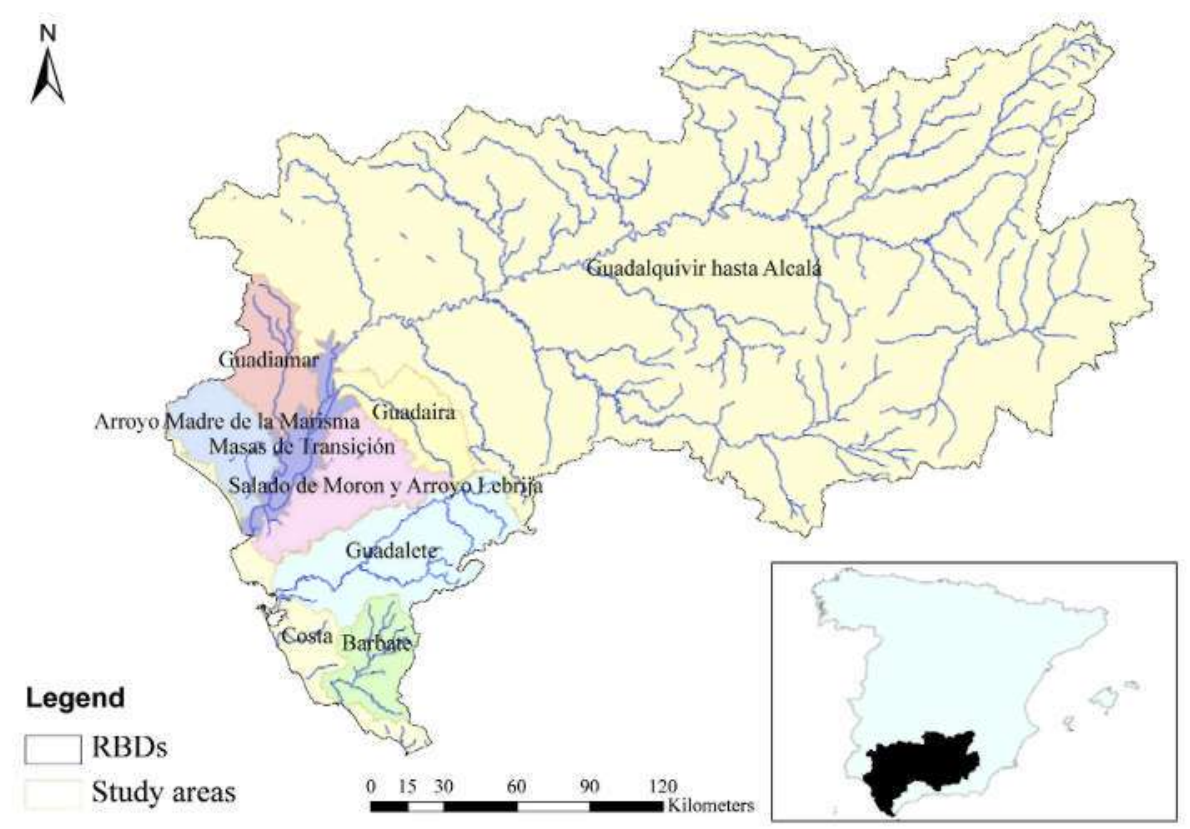

Fig. 2. Study areas and main rivers in the Guadalquivir, Guadalete, and Barbate river basins.

footprint was calculated by estimating the excess nitrogen leached. The crop nitrogen extraction was considered to be $50 \mathrm{kgN} / \mathrm{t}$ of raw cotton produced (López Bellido, 2003), and this figure was multiplied by the crop yield per irrigation technique to obtain the total nitrogen extractions per ha. In 2004, an average of $200 \mathrm{kgN} / \mathrm{ha}$ was applied, whereas it fell to only $90 \mathrm{kgN} / \mathrm{ha}$ in 2008 (Arriaza and Capellán, 2009). The difference between nitrogen extraction and applied nitrogen was considered as the excess nitrogen from which $15 \%$ is leached in the Guadalquivir valley according to Velthoft et al. (2007). Leaching was assumed to be negligible in the case of rainfed production. The nitrogen concentration limit was considered to be $50 \mathrm{mg} \mathrm{NO} / 1$, in accordance with the EU Nitrates Directive (EC, 2002; EU 91/676/EEC).

Only the water incorporated into the product was taken into account in the cotton-ginning phase, which occurs with dried cotton (humidity is lowered from $7-9 \%$ to $3-5 \%$ ). This humidity content is restored at the end of the process to avoid fire risk and to facilitate the ensuing industrial phases (López-Bellido, 2003).

With regard to the Lyocell fibre, the calculation of the green water footprint of wood production was performed by estimating the evapotranspiration of deciduous forests in Europe (van Oel and Hoekstra, 2012). The wood yield and pulp processing processes were according to the LCA published by the Lenzing Group (Shen et al., 2010). The estimations of processing water used in pulp production were based on the working draft of best available technologies for Kraft processes, non-integrated pulp mills (EC, 2012). The estimation of water consumption in the production phase was based on the data supplied by the producing company, Lenzing Group. The emission values of the Lyocell and pulp production processes were obtained from the Austrian standard for surface water quality for this sector (BLFUW, 2000a, 2000b).

\subsubsection{Fabric production stage}

Five different fabric types where considered for fabric production (spinning, dyeing, and weaving stages). All of the fabrics differ in their final characteristics, covering the main categories of textile for trousers, and included two cotton denim materials (colours 82 and 212) plus two other cotton fabrics, one dyed in the weaving phase and one "ready to dye" or dyed after the weaving phase in a separate phase, and one Lyocell fibre denim fabric (colour 390).

The water footprint per unit will be influenced by the subsequent processes (spinning, dying, weaving, and finishing), which depend on the characteristics of the final product. In this study, all of the water consumed in the spinning and weaving phases was measured in a fabric-producing plant of the company Tejidos Royo in Picassent (Spain). AlTEX, the Textile Industry Research Association, collaborated in the data collection. The water consumed depends on the different processes followed to obtain a specific fabric, particularly for the dying with indigo and subsequent washing steps.

The grey water footprint was calculated with the effluent chemical oxygen demand of the factory and compared to the specific discharge permitted by the municipal authorities. Both the spinning and weaving steps occur in the same factory, and the grey water footprint was estimated jointly. The calculation of the garment's WF (jean trousers) was estimated by considering an average weight of $780 \mathrm{~g}$ per unit. The water used in the confection phase was not taken into account.

\subsection{Blue water impact assessment}

The blue water footprint impact assessment was performed in the cotton production phase by following the methodology of the Water Footprint Assessment Manual (Hoekstra et al., 2011). The methodology includes the estimation of the blue water stress index per month at the river basin level. This index is the ratio of the total blue WF in the study area to the blue water availability (BWA). This availability is calculated as the difference between the river flow under natural conditions and the environmental minimum flow requirements (EFRs):

$\mathrm{WS}_{\text {Blue }}[x, t]=\sum \mathrm{WF}_{\text {Blue }}[x, t] /\left(R_{\text {nat }}[x, t]-\operatorname{EFR}[x, t]\right)$

where

$\mathrm{WS}_{\mathrm{Blue}}[x, t]$ is the blue water scarcity (dimensionless) per river basin, $x$, and time frame (month), $t$; 
$\mathrm{WF}_{\mathrm{Blue}}[x, t]$ is the total blue water footprint per river basin and month $\left(\mathrm{Mm}^{3} / \mathrm{y}\right)$;

$R_{\text {nat }}[x, t]$ is the natural runoff in the catchment for a time frame (month) $\left(\mathrm{Mm}^{3} / \mathrm{y}\right)$; and

EFR $[x, t]$ is the environmental flow requirement $\left(\mathrm{Mm}^{3} / \mathrm{y}\right)$.

This index considers the theoretical natural runoff (not the actual runoff) as the basis for the estimation of the water availability (the denominator in Eq (1)), as suggested by Hoekstra et al. (2011). In our case, we divided the Guadalquivir and the Guadalete and Barbate River Basin District into smaller sub-basins that served as the study areas so that the different information could be combined (Fig. 2). The EFR at the end of each sub-basin was known, as it is given in the River Basin District Management Plan (RBDMP).

In this work, we also took into account the available water stored in dams. This was estimated as the actual monthly volume stored in the dams in those years minus the dependent urban and industrial demands and the environmental minimum requirement for each dam, as calculated for each study area. Thus, an adjusted WSI index was calculated.

The blue water footprint per crop, year, and municipality was estimated for all the study areas by following the methodology in Salmoral et al. (2011a), as based on Garrido et al. (2010), and taking into account irrigation limitations as a consequence of the drought level per irrigation district. A more realistic estimation of the blue WF of crop production may be obtained in this way. The estimated yearly crop WF was distributed among the different months of the year according to the estimated blue water requirements in Garrido et al. (2010). The blue WF of all crops and municipalities of a study area was then aggregated using the information of the crop irrigated surface at the municipal level given by the Ministry of Agriculture, Food and Environment. For municipalities that are located partly outside of the basin or that are situated in more than one study area, the municipalities' water consumption was assigned to each study area proportionally based on the area of the municipality inside the study area. The result is the crop blue WF of the study area, which is equal to the total blue WF of the study area in Eq (1), and was used for the calculation of blue water availability. In the Guadalquivir basin, the crop blue WF represents $80 \%$ of the total blue WF of all uses (Salmoral et al., 2011a).

The data for the natural river flow $\left(R_{\text {nat }}\right)$ was obtained from RBDMP and is based on the SIMPA hydrological model (Estrela and Quintas, 1996), which is used by the Spanish River Basin authorities in their resource estimation. This model estimates the total runoff per $100 \times 100$-m grid cell. The average $1940 / 41-2005 / 06$ monthly accumulated runoff at the study area's endpoint was used. The ecological flow at the end of the study areas and the municipal urban and industrial water demand and ecological flow at the end of each dam was obtained from the RBDMP (DHG, 2009, 2012 in the Guadalquivir and AAA, 2010 in the Guadalete and Barbate basins). The stored capacity in dams and dam outflow at the end of the study areas were obtained from the River Basin District information tool (SAIH, 2012).

As stated in RBDMP, the environmental flows of the Guadalquivir's estuary (Transition Water bodies) are complex and depend on the sea dynamics; thus these factors are not included in the present analysis. The same reasoning was applied to small coastal rivers. The different information was geographically added using ArcGIS 9.3.

\section{Results}

\subsection{Water accounting}

Table 1 shows the maximum, minimum, and average water footprints in each production stage in both production chains (cotton and Lyocell) and the final WF per item.

In the process of the Lyocell fibre, the main consumption lies in the wood growth stage, which relies mainly on green water, and the water footprint of wood varies depending on the origin of the wood and forest type (Van Oel and Hoekstra et al., 2012). The maximum values shown here account for broadleaf forest from central Europe, the actual origin of the wood, and the minimum values account for temperate eucalyptus forests from South Africa, an alternative wood source that is used by the company to produce fibres other than Lyocell (Shen et al., 2010). These values are averages of various years and locations. Other possible wood origins were not considered because, as provided by the manufacturer company, the sources used are those from which the wood for Lyocell fibre may ultimately be derived.

Both cellulose pulp production and fibre production from the pulp exhibit a lower water footprint than the wood growth phase, albeit of a different nature. Green water is the main component in the wood growth phase, whereas grey water is dominant in the industrial phases. The existing technologies allow for industrial plants to almost completely reuse the water used in their processes, and the effluents are reportedly within the legal environmental limits. This causes the industrial WF to be small. Water consumption and pollution in the spinning and weaving phases differ according to the specifications of the fabric and are mainly related to the final colour and appearance of the product. Different processes are followed to achieve these specifications. Dying, for example, requires water for the application of the colour and subsequent washings to remove the surplus dye. In the case of the Lyocell fibre, only one product is assessed, and, therefore, only one process is followed.

Additionally, in the case of the cotton products, the cotton growth phase shows the highest water footprint values $\left(\mathrm{m}^{3} / \mathrm{t}\right)$ and

Table 1

Maximum, minimum and average green, blue and grey water footprint $\left(\mathrm{m}^{3} / \mathrm{t}\right.$ product) in each production stage and total WF per trouser $\left(\mathrm{m}^{3} /\right.$ piece).

\begin{tabular}{|c|c|c|c|c|c|c|c|c|c|c|c|c|c|c|}
\hline \multirow[t]{2}{*}{ Cotton products } & \multicolumn{4}{|c|}{ Cotton lint $\left(\mathrm{m}^{3} / \mathrm{t}\right)$} & \multicolumn{3}{|c|}{ Ginning $\left(\mathrm{m}^{3} / \mathrm{t}\right)$} & \multicolumn{3}{|c|}{ Spinning and weaving $\left(\mathrm{m}^{3} / \mathrm{t}\right.$ fabric $)$} & \multicolumn{4}{|c|}{ Total WF of cotton trousers $\left(\mathrm{m}^{3} / \mathrm{item}\right)$} \\
\hline & Green WF & Blue WF & Grey & & Green WF & Blue WF & Grey WF & Green WF & Blue WF & Grey WF & Green WF & Blue WF & Grey WF & Total WF \\
\hline $\operatorname{Max}\left(m^{3} / t\right)$ & 879 & 6339 & 550 & & 0 & 30 & 0 & 0 & 134.3 & 0.06 & 544 & 4008 & 341 & 4894 \\
\hline $\operatorname{Min}\left(\mathrm{m}^{3} / \mathrm{t}\right)$ & 302 & 3862 & 272 & & 0 & 60 & 0 & 0 & 53.5 & 0 & 187.9 & 2439.4 & 169.4 & 2797 \\
\hline Average $\left(\mathrm{m}^{3} / \mathrm{t}\right)$ & 422 & 4380 & 326 & & 0 & 40 & 0 & 0 & 91.76 & 0.06 & 263 & 2767 & 203 & 3233 \\
\hline \multirow[t]{3}{*}{$\begin{array}{l}\text { Lyocell fibre } \\
\text { products }\end{array}$} & \multicolumn{3}{|c|}{ Wood growth $\left(\mathrm{m}^{3} / \mathrm{t}\right)$} & \multicolumn{4}{|c|}{$\begin{array}{l}\text { Fibre production (market pulp } \\
\text { Lyocell process) }\end{array}$} & \multicolumn{3}{|c|}{$\begin{array}{l}\text { Spinning and weaving } \\
\left(\mathrm{m}^{3} / \mathrm{t} \text { fabric) }\right.\end{array}$} & \multicolumn{4}{|c|}{ Total WF of Lyocell trousers $\left(\mathrm{m}^{3} / \mathrm{item}\right)$} \\
\hline & Green & Blue & Grey & $\mathrm{Gr}$ & $\operatorname{sen}$ & Blue & Grey WF & Green & Blue & Grey & Green & Blue & Grey & Total \\
\hline & WF & WF & WF & WI & & WF & & WF & WF & WF & WF & WF & WF & WF \\
\hline $\operatorname{Max}\left(\mathrm{m}^{3} / \mathrm{t}\right)$ & 1012 & 0 & 0 & 0 & & - & 3.71 & 0 & 104.8 & 0.06 & 1652.9 & 46.7 & 175.6 & 1875 \\
\hline $\operatorname{Min}\left(\mathrm{m}^{3} / \mathrm{t}\right)$ & 682 & 0 & 0 & 0 & & 0 & 272.1 & 0 & 104.8 & 0 & 1115 & 46.4 & 2.4 & 1164 \\
\hline Average $\left(\mathrm{m}^{3} / \mathrm{t}\right)$ & 847.1 & 0 & 0 & 0 & & 1 & 56.7 & 0 & 104.8 & 0.06 & 1384 & 34.5 & 35.3 & 1454 \\
\hline
\end{tabular}

Source: Own elaboration based on own calculations, data collected in Tejidos Royo with the help of AITEX and data supplied by Lenzing Group. 
variability, (taken as a larger difference between the maximum and minimum). As explained, higher values in the spinning and weaving phases are related to darker colours (which require higher dyeing doses and stronger washing after dying). In contrast to the wood-based lyocell fibres, the blue water footprint is predominant in cotton production, though grey water is also significant.

Accordingly, we focused the sustainability assessment of the jeans product on the cotton-producing stage, as this stage shows the highest water footprint within the value chain. An analysis to evaluate the variation and impacts of this consumption was performed. The Spanish cotton production was analysed at a municipal level. Because of the significant impact of the CAP reform on cotton production, the years 2005 and 2009 were selected so that the impact of CAP decoupling on the crop water footprint could be analysed. The WF per unit $\left(\mathrm{m}^{3} / \mathrm{t}\right)$ was calculated as a first step.

Fig. 3 shows the average water footprint $\left(\mathrm{m}^{3} / \mathrm{t}\right)$ of cotton production for the years 2005 and 2009 per irrigation method; the land productivity (euro/ha) excluding CAP's subsidies is also shown. As a consequence of the decoupling of the EU Common Agricultural Policy payments, the response of farmers to maintain profitability was to minimise variable costs, reducing irrigation and

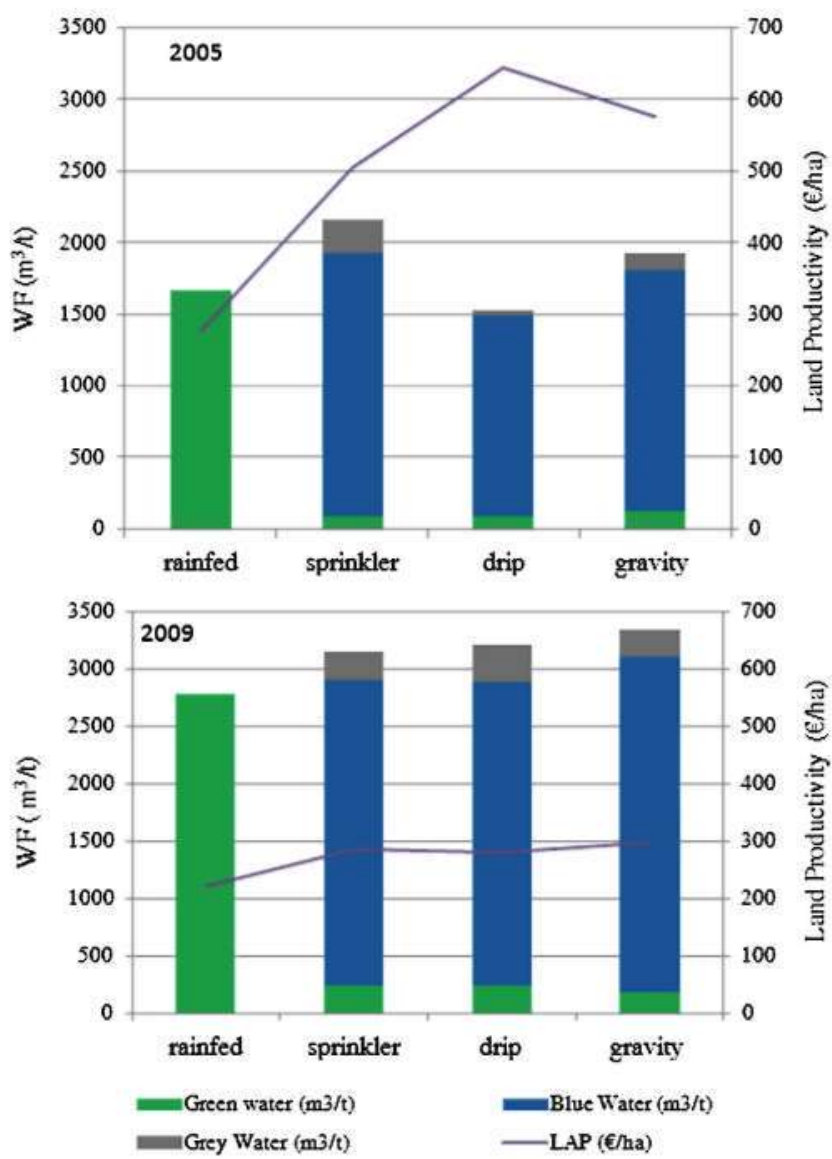

Fig. 3. Water footprint $\left(\mathrm{m}^{3} / \mathrm{t}\right.$, columns, left axis) and land productivity (LAP) (C/ha, line, right axis) per irrigation method for the years 2005 and 2009. fertiliser use and altering other agricultural practices, which resulted in lower yields, thus increasing the water footprint per unit. In the case of cotton production, a more extensive production is less efficient with regard to green and blue water consumption. Nevertheless, fertilisation and available nitrogen decreased, the yield reduction was even higher, causing the grey WF per unit to increase in 2009 compared to 2005.

Land productivity was significantly smaller, thus less economic value is obtained per unit area, and farm profitability is threatened.

However, the relationship between the blue, green, and grey WF was reversed between 2005 and 2009: blue WF increased by $50 \%$, grey water increased by $101 \%$, and green water by $275 \%$. Variance in the WF was also significant and higher in the 2009 than in 2005. Table 3 shows the averages obtained and standard deviations in the results per municipality for green, blue, and grey WF (Table 2). Water consumption increased in variability among municipalities after the reform in 2008. There is a correlation between irrigation management and nitrogen losses. Cavero et al. (2012) studied this relationship in three semiarid areas, reporting that irrigation management was more relevant for nitrogen control than good fertilisation management. This result suggests the interrelation of blue and grey water footprints because irrigation with lower, more frequent water applications reduces nitrogen lixiviation but increases the blue water footprint as the evaporation increases.

Regarding the overall cotton WF, Fig, 4 represents the municipal cotton water footprint per year. Although the WF per unit of product $\left(\mathrm{m}^{3} / \mathrm{t}\right)$ increased, the total cotton WF in the basin decreased as the cultivated surface diminished from 85,700 ha in 2005 to 58,477 ha in 2009. The total green WF decreased from 35 to $27 \mathrm{Mm}^{3}$ and the blue WF from 455 to $197 \mathrm{Mm}^{3}$ between 2005 and 2009. The total grey water footprint decreased by more than half, from 32 to $15 \mathrm{Mm}^{3}$ during this period.

The lowering of the overall WF of cotton production has contributed to lower the pressure of water resources in the basin. The setting of cotton production's WF in the basins' context was then analysed.

\subsection{Blue water sustainability assessment}

The theoretical water availability was set against the river flow and water stored in reservoirs (which is used for irrigation and also for urban supply, hydropower and river regulation, and environmental flow) as a comparison point. Table 3 shows the average natural runoff, environmental flow minimums, stored water, and basin outflow for the main body of the Guadalquivir River study area in 2005 and 2009 and the results for the available water, crop blue water footprint in 2005 and 2009, and WSI in 2005 and 2009.

According to RBDMP, in the Guadalquivir river basin urban water withdrawal amounts to $380.39 \mathrm{Mm}^{3} / \mathrm{y}$. Industrial water use, either directly from surface water bodies or from the urban network, represents $71.77 \mathrm{Mm}^{3} / \mathrm{y}$. Irrigation water demand (including losses and return flows) is estimated at $3495 \mathrm{Mm}^{3} / \mathrm{y}$ in the same documents. The demand for livestock adds $3.03 \mathrm{Mm}^{3} / \mathrm{y}$ (direct consumption by animals).

The crop blue water footprint exceeds the naturally available water from June to September, both in 2005 and 2009, causing the

Table 2

Average green, blue and grey WF $\left(\mathrm{m}^{3} / \mathrm{t}\right)$ and standard deviation among municipalities.

\begin{tabular}{|c|c|c|c|c|c|c|}
\hline Year & Av. Green WF $\left(\mathrm{m}^{3} / \mathrm{t}\right)$ & Av. Blue WF $\left(\mathrm{m}^{3} / \mathrm{t}\right)$ & Av. Grey WF $\left(\mathrm{m}^{3} / \mathrm{t}\right)$ & SD municipal green WF & SD municipal blue WF & SD municipal grey WF \\
\hline 2005 & 133.2 & 1648.1 & 113.3 & 33.8 & 188.3 & 73.2 \\
\hline 2009 & 499.8 & 2473.4 & 228.78 & 397.6 & 581.9 & 110.5 \\
\hline
\end{tabular}

Source: Own elaboration. 


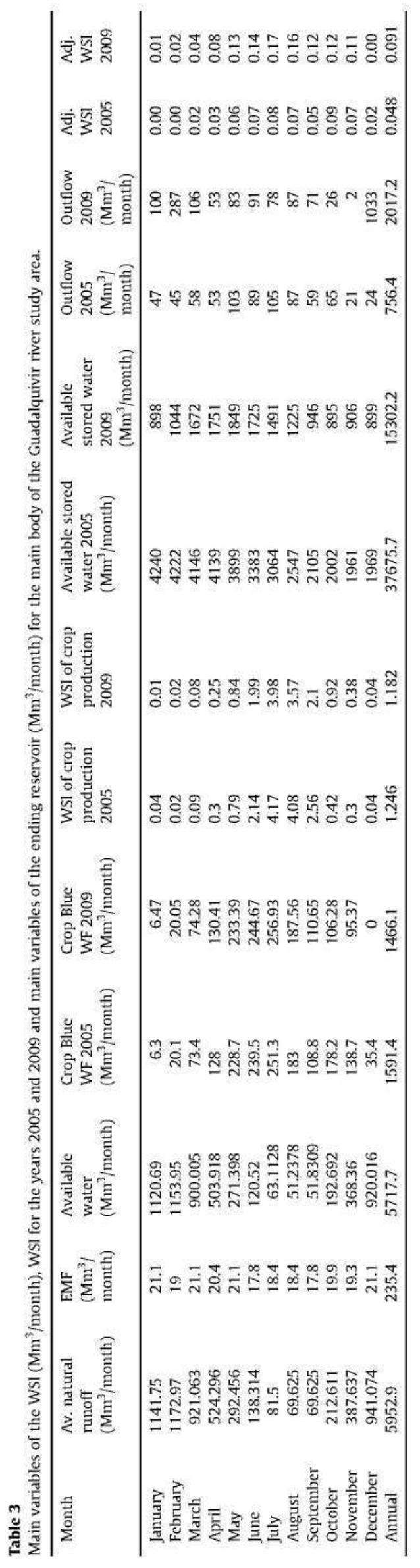

WSI to exceed 1 . This means that, theoretically, crop production is over-using water resources in these months and, therefore, is not meeting environmental standards. In this case, we observe that the real outflow of the study area is higher than the environmental minimum, except in November 2009. This result shows that the dam sitting at the end of this study area meets the environmental minimum requirement, at least in terms of quantity. However, the adjusted WSI, based on the available stored water reaches a maximum of 0.17 for the entire year. In fact, crops are irrigated from the water stored in the reservoirs during the previous months and years. The Guadalquivir river basin has a total storage capacity of $7145 \mathrm{Mm}^{3}$ (this figure includes all the study areas, except the coastal area and Guadalete and Barbate river basins), and the stored water is higher than the estimated blue WF in the main body of the Guadalquivir river. It is this regulation of the river that determines availability in the basin and, therefore, the fulfilment of the environmental flow requirements and water availability in the basin. Nevertheless, the available stored water provides a reserve for several months (and not only for one month), providing carry-over resources for the next year. In its management, the River Basin District considers that demands are satisfied when the water deficit for urban use is less than $10 \%$ in a year and less than $50 \%$ for agricultural use; these are the actual thresholds signalling water deficit in the basin. However, a significant amount of agriculture in the Guadalquivir basin is irrigated with groundwater (Salmoral et al., 2011a), which would not be included in the estimated WF. It is estimated that $30 \%$ of the total irrigation consumption is groundwater derived in the Guadalquivir RBD, with $20 \%$ in the Guadalete and Barbate RBDs (DHG, 2012; Salmoral et al., 2011a; De Stefano et al., 2012).

Table 4 provides the average cotton WF, aggregation of the total crop blue WF, natural runoff, naturally available water, average monthly available water storage, and water flow data for all the study areas for the years 2005 and 2009 . The average WSI in cottonproducing months and an adjusted WSI calculated using the outflow from dams instead of the natural runoff are also shown.

Table 4 shows that the naturally available water from April to October is lower than the blue WF of the basins. The average of the WSI in these months largely exceeds the limit of the naturally available resources. If we consider the available stored water, the total available water is still lower, though the adjusted WSI is lower than the WSI based on natural flows because the basins' river dams have actually partially reversed the natural cycle. The flows in summer do not decrease as much as they would if natural conditions were maintained to satisfy water usage. Nevertheless, in both cases, the decrease of the basin's blue WF lowered the water stress, showing a smaller WSI in 2009 compared to 2005. The Guadalquivir river basin has improved the efficiency of its agricultural water use, even though the irrigated area has increased (Salmoral et al., 2011a; JA, 2010).

\section{Discussion}

The WF methodology allows for the estimation of water resource appropriation by human activities (Hoekstra et al., 2011). For consumer products, the points of the production chain where this appropriation occurs have been identified, providing information that enables the connection between consumption and production to be defined in a clear manner. We estimated the WF of a consumer product, blue jeans, and identified fibre production as the main water-consuming phase. Significant differences were found between cotton-based products and cellulose-based fibres. Indeed, Lyocell fibre production is based on green water, which, in most cases, implies reduced impact on water resources. Moreover, as publicly stated by Lenzing Company (Shen et al., 2010), the origin 


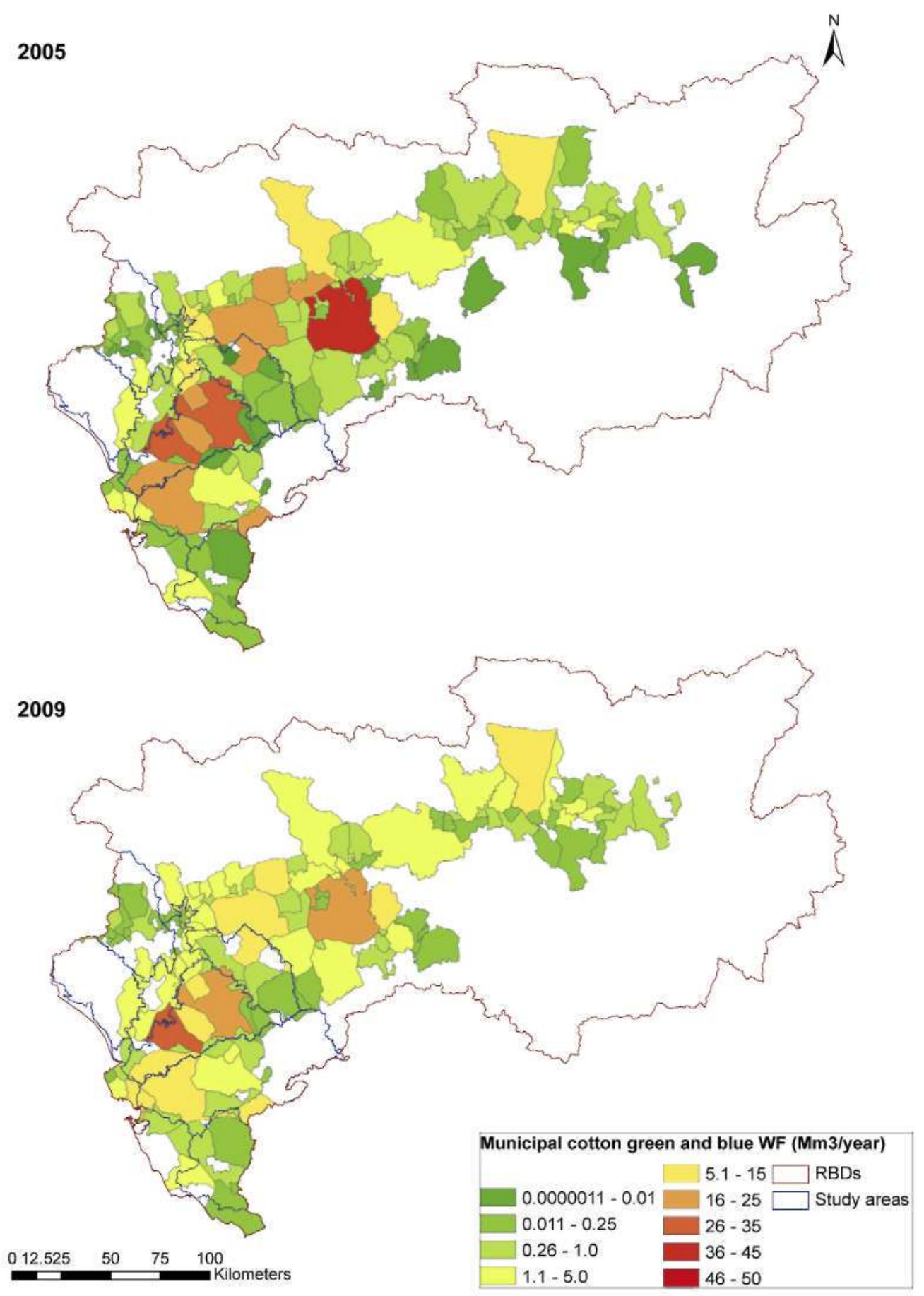

Fig. 4. Municipal cotton green and blue water footprints $\left(\mathrm{Mm}^{3} / \mathrm{y}\right)$. (For interpretation of the references to colour in this figure legend, the reader is referred to the web version of this article.

of the wood for the cellulose is managed forests. Nevertheless, some authors discuss the trade-off between land use and green water consumption (Jewitt, 2006) and recommend the assessment of the ecosystem services provided by natural green water consumption (Willaarts et al., 2012).

In the case of cotton production, the values shown in Table 5 account for Spanish production, as estimated in this study. As a reference point, Table 5 shows the values for the main producing countries worldwide, as reported by Mekonnen and Hoekstra (2010). Turkey and Syria are included because they represent Spain's main cotton export countries.
There are clear differences between the world's main producers, China and the USA, which rely on green water, and the remainder of the displayed countries, which have semiarid climates and where blue water plays an important role. Although the values present similarities between countries, these are averages of both regions and years. Indeed, the differences for Spain can be greater than $50 \%$ in one area. WFs exhibit a wide variability between and within regions because of the local conditions or different production technologies. Several studies have shown significant variability in the WF of an agricultural product. Salmoral et al. (2011b) and Chico et al. (2010) studied the cases of Spanish olive oil and tomato production. 
Table 4

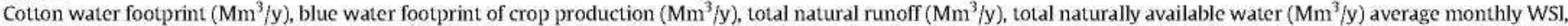
average monthly water storage ( $\mathrm{Mm} 3 / \mathrm{month})$, total outflow $\left(\mathrm{Mm}^{3} / \mathrm{y}\right)$ and average adjusted WSI in cotton producing months (April-October).

\begin{tabular}{|c|c|c|c|c|c|c|c|c|}
\hline Year & $\begin{array}{l}\text { Cotton WF } \\
\left(\mathrm{Mm}^{3} / \mathrm{y}\right)\end{array}$ & $\begin{array}{l}\text { Total crop } \\
\text { blue WF } \\
\left(\mathrm{Mm}^{3} / \mathrm{y}\right)\end{array}$ & $\begin{array}{l}\text { Total } \\
\text { natural } \\
\text { runoff }\end{array}$ & $\begin{array}{l}\text { Total } \\
\text { available } \\
\text { water } \\
\text { (natural runoff - } \\
\text { EFR, } \mathrm{Mm}^{3} / \mathrm{y} \text { ) }\end{array}$ & $\begin{array}{l}\text { Average monthly WSI } \\
\text { (crop blue WF/Available } \\
\text { water, per study area) }\end{array}$ & $\begin{array}{l}\text { Monthly Available } \\
\text { water in Dams } \\
\left(\mathrm{Mm}^{3}, \text { Av. April- }\right. \\
\text { October) }\end{array}$ & $\begin{array}{l}\text { Total outflow } \\
\left(\mathrm{Mm}^{3} / \mathrm{y}\right)\end{array}$ & $\begin{array}{l}\text { Average adjusted } \\
\text { monthly WSI } \\
\text { (crop blue WF/ } \\
\text { Monthly outflow) }\end{array}$ \\
\hline 2005 & 454.4 & 2532 & 1854.9 & 1704 & 5.59 & 3949 & 1066.9 & 1.67 \\
\hline 2009 & 196 & 2457 & 1854.9 & 1702.4 & 4.55 & 2222.6 & 860.31 & 1.18 \\
\hline
\end{tabular}

Mekonnen and Hoekstra (2010) estimated worldwide per region and country green, blue and grey WF of an ample selection of crops and animal products. Ridoutt et al. (2011) showed the differences among production systems in the livestock sector.

Pfister et al. (2009) analysed the variation of cotton water consumption, reporting that the variation is greater within a country (for the main producing countries) than among countries. A river basin or even a smaller unit is better assessment scale for the water footprint of a product. In the case of specific consumer products, the spatial and temporal differences in WF make it necessary to study water consumption at the lowest possible scale to provide accurate estimations for the product value chain.

In their study of the water footprint of the Guadalquivir river, Salmoral et al. (2011b) report that the total blue WF represents $9 \%$ of the precipitation falling in the basin. For a hydrologically normal year (2003), these authors estimated the total runoff as $6088 \mathrm{Mm}^{3}$ / $\mathrm{y}$, similar to the average data used herein, and their estimates of the agricultural blue water footprint in the Guadalquivir basin were $2290 \mathrm{Mm}^{3}$ for 2003 and $1470 \mathrm{Mm}^{3}$ for 2008 . These values are similar to those reported in the present study because we based our calculation on their methodology and adjusted the available irrigation water to the crop type and type of hydrological year. The data reported in Table 3 correspond to a fraction of the basin. Using a methodology based on the RBDMP's water allocations per crop and data from 2004, Montesinos et al. (2011) estimated the blue WF of the Guadalquivir basin to be $1755 \mathrm{Mm}^{3}$.

The apparel industry procures its raw materials from a variety of sources, thus the water footprint of its products may vary significantly. This forms the core of the industries' environmental responsibility: learning how suppliers can pollute less and become more efficient. Field results are more variable than the country and regional averages, and this offers opportunities for companies that intend to lower the environmental pressure of their products. A company's logical response could be to select providers that are more efficient in water use by taking advantages of agronomical practices and technology that significantly yield the best results. Indeed, the agricultural practices could bear improvements with regard to the environment.

Table 5

Average water footprint of the fibres $\left(\mathrm{m}^{3} / \mathrm{t}\right)$.

\begin{tabular}{|c|c|c|c|c|}
\hline & $\begin{array}{l}\text { Green WF } \\
\left(\mathrm{m}^{3} / \mathrm{t}\right)\end{array}$ & $\begin{array}{l}\text { Blue WF } \\
\left(\mathrm{m}^{3} / \mathrm{t}\right)\end{array}$ & $\begin{array}{l}\text { Grey WF } \\
\left(\mathrm{m}^{3} / \mathrm{t}\right)\end{array}$ & $\begin{array}{l}\text { Total WF } \\
\left(\mathrm{m}^{3} / \mathrm{t}\right)\end{array}$ \\
\hline China $^{a}$ & 3258 & 558 & 1477 & 5294 \\
\hline Spain $^{a}$ & 902 & 4876 & 0 & 5778 \\
\hline Turkey ${ }^{a}$ & 1076 & 5271 & 490 & 6836 \\
\hline $\begin{array}{l}\text { United States } \\
\text { of America }\end{array}$ & 4781 & 2043 & 483 & 7307 \\
\hline Uzbekistan $^{a}$ & 794 & 7556 & 0 & 8350 \\
\hline Syria $^{\text {a }}$ & 152 & 4669 & 397 & 5218 \\
\hline Cotton ${ }^{b}$ & 422 & 4380 & 326 & 5128 \\
\hline Lyocell fibre ${ }^{b}$ & 2223 & 0.58 & 57 & 2285 \\
\hline
\end{tabular}

a Source: Mekonnen and Hockstra (2010).

b Source: Own elaboration.
Hurtado et al. (2011) estimated the nitrogen losses from the lower Guadalquivir area with artificial drainage under cotton cultivation in 2003 , reporting that $6-8 \%$ of applied nitrogen is lost and suggesting inadequate nitrogen management for this typical fertilisation behaviour. Santos et al. (2010) studied an irrigation scheme in the basin in detail and report a varying acceptance of the recommendations from the irrigation advisory service by farmers, leading to varying efficiencies in irrigation performance, both over- and under-satisfying crop water requirements.

Lorite et al. (2012) observed that cotton farmers irrigated between 29 and 57\% below the recommended amount in the 2006 and 2007 seasons, emphasising the change in CAP payments, irrigation water availability, and differences in the response to deficit irrigation between crops. In a detailed study on Andalusian cotton production, Arriaza (2008) reported decreases of $55 \%$, and $67 \%$ in fertiliser use, with the farmers declaring their intention of also reducing pesticide use. Wheat, sunflower, citrus, and olive tree cultivation have substituted for cotton. The number of cotton producers decreased from 9445 in 2004/05 to 6979 in 2007 (JA, 2008), and the working hours needed by the crop decreased by $20 \%$ between 2003 and 2006 and 2007 (García-Vila et al., 2008).

However, due to a change in the CAP's support to EU cotton production, the total WF $\left(\mathrm{Mm}^{3}\right)$ decreased by $65 \%$ because the cultivated surface decreased more than the increase in WF per ton produced. Giannoccaro and Berbel (2011) report that the response to a reform of CAP payments is influenced by the geographical situation of the farm. In the case of Andalusia (contrary to the overall EU-wide result). Their survey shows that most of the farmers would modify their water use if the CAP payments were to be removed, both with regard to increasing and decreasing usage. Farming practices respond to incentives, including the price obtained per product and CAP payments. Accordingly, the production methods changed significantly as the subsidy's incentive disappeared.

Nevertheless, within a context of higher product prices, the response of cotton producers is to intensify production. As the price paid for raw cotton increased by $90 \%$, the cultivated surface and yields obtained increased by 14 and $50 \%$ in the years $2008-2010$, respectively (MAGRAMA, 2012). In the analysis made for cotton production in Spain, it was shown that the extensification of production has led to a higher WF per ton produced (average of $50 \%$ increase) and lower harvest value, which is partially compensated for by the CAP's subsidy. However, the environmental consequence of this is ambiguous. When production was less intensive, the pressure on water resources per unit increased at the individual level because production was less efficient; however, the overall pressure decreased because a smaller surface area was cultivated. There is a need to move toward sustainable intensification of agricultural systems to restore systems and increase the efficiency of resource use (natural/human/economic).

This is a very important factor to consider when attempting to develop more environmentally friendly products, as it may impact the effectiveness of the efforts taken. Companies aiming to generate products with less environmental pressure could achieve products 
with less WF; however, if enough incentives are provided, the overall water consumption and total amount of agrochemicals reaching the water bodies may increase. Another possibility is that the company's efforts do not ameliorate the environmental situation of a river basin if their influence is restricted to a product. This could be the case in the Guadalquivir basin where cotton represents only $7 \%$ of the basin's blue WF. The overall state of a specific basin may be out of the scope of a specific company, as the status depends on the product's relevance to the basin's water issues. In this case, more extensive cotton production has not substantially reduced the WF of the study basin.

Our results show that measuring only WF per unit is not sufficient to evaluate a product's sustainable use of resources. Because resources are shared by many uses and production chains, independently of the performance of a specific product, the entire basin may behave worse or better than a particular set of products. The WF per unit of a product has to be considered within the relevant context to be meaningful and relevant to policy. A more intensive production will generally be accompanied by a reduced WF. However, as WF is a relative indicator, it does not reflect the overall load on the resources in the river basin.

Because the production context has a high relevance, there is a need for a second phase of analysis that includes an impact assessment, and there is a need to weigh the obtained water consumption with water stress coefficients to make the results among sites comparable (Ridoutt and Pfister, 2012). This was reflected in the calculated WSI. However, as the river basin studied is highly regulated, calculating the available water from the natural runoff was not completely informative with regard to the existing water availability, even after the environmental flows were taken into account. In regulated rivers, this existing infrastructure conditions the river functioning and enables the maintenance of the ecological functions. To highlight this, we compared both the available water stored in the study years and the measured outflow in the endpoints of the study areas with the EFR and water naturally available from runoff. This allowed us to also include very specific temporal and spatial variations in the WSI. In principle, the stored water is greater than the agricultural demand, but the river flows do not always satisfy EFR. Urban and energy users also condition the use of water for irrigation. Institutional arrangements (for example, drought management plans, insurance, or water banks) and technological solutions (for example, reservoirs, irrigation technologies, or water re-use) introduce flexibility and possibilities for the management of resources, allowing human activities to increase their use of natural resources while minimising its impacts. It is very difficult to incorporate such factors as indicators, and these factors need a deeper assessment, and high-resolution information (Berger and Finkbeiner, 2010).

\section{Conclusions}

WF accounting is a helpful tool for the identification of relevant water consumption and pollution in the value chain, and significant differences are found between product categories. Cellulose-based Lyocell fibre has a notably lower water consumption than cotton fibres, on average $1384,34.5$, and $35.3 \mathrm{~m}^{3} / \mathrm{t}$ as opposed to 263,2767 , and $203 \mathrm{~m}^{3} / \mathrm{t}$ for green, blue, and grey water, respectively. WF accounting is also useful to analyse water use at a disaggregate level, allowing its connection with production and consumption, both spatially and temporally, and the study of the drivers and trends of water use. However, WF accounting results have to be interpreted with caution, as they need to be considered within the appropriate context to be meaningful. A second phase of sustainability assessment is needed to study the environmental impact and socioeconomic context of this consumption.
Independently of its relative weight in a region, the impact of specific agricultural production is determined by the aggregate response of many activities. Addressing the minimum WF per unit $\left(\mathrm{m}^{3} / \mathrm{t}\right)$ may only partially affect the river basin status. Price incentives and public policies affect the response of farmers, but the collective result of all users is the one that influences the sustainability of water consumption in a region. These incentives may heavily affect the water consumption of a specific production system and need to be taken into account by companies trying to improve their water management. Although some of these incentives may fall out of the scope of a particular company, such as those originating from the Common Agricultural Policy, which only influence EU farmers, a good understanding of them may improve the effectiveness of a company's efforts to achieve environmentally friendlier products.

Weighing WFs with stress indicators assists in defining them with regard to the local water scarcity and in comparing between years and basins. Nevertheless, the definition of water scarcity is complex, and technological and institutional tools may also be crucial for an area to manage its resources efficiently and prioritise the uses that it considers most important. All these factors are difficult to combine into a single indicator, and broader studies of the area are needed for a complete understanding of the impact of water use.

\section{Acknowledgements}

This work was done with the assistance of Inmaculada Del Moral (Aitex), Jorge Solano and Antonio Almela (Tejidos Royo) and Lenzing Gruppe, producers of Tencell Fibre (Lyocell Fibre).

\section{References}

AAA, 2010. Guadalete and Barbate River Basin Management Plan. Andalusian Water Agency (in Spanish) (online, accessed on 24.03.13.) Available at: www. juntadeandalucia.es/medioambiente/site/portalweb/menuitem.7e1cf46ddf59bb 227 a 9 ebe $205510 \mathrm{e} 1 \mathrm{ca} / ?$ vgnextoid 66db6ff4a9743310VgnVCM2000000624e 50 aRCRD\&; vgnextchannel 75b3e6f6301f4310V gnVCM2000000624e50aRCRD.

Allen, R.G., Pereira, I.S., Raes, D., Smith, M., 2006. Crop Evapotranspiration Guidelines for Computing Crop Water Requirements - FAO Irrigation and Drainage Paper 56. Food and Agriculture Organization, Rome, Italy (online, accessed 24.03.13.) Available at: ftp.fao.org/agl/aglw/docs/idp56s.pdf.

Alliance for Water Stewardship, 2012. International Water Stewardship Standard. First Draft for Stakeholder Input. Version 03.13.2012. (online, accessed 24.03.13.) Available at: www.allianceforwaterstewardship.org/assets/documents/AWS Standard First Draft v 03132012 pdf.

Arriaza, M., 2008. Progressive extensification of the cotton production in Spain. In: Proceedings of International Cotton Conference "Rationales and Evolution of Cotton Policies", 50-55. May 13-17, 2008. Montpellier (France).

Arriaza, M., Capellán, H., 2009. Effects of the cotton reform in Spain. Cahiers Agricultures 18 (5), 408-416, 1166-7699.

Bayart, J.B., Bulle, C., Deschênes, I., Margni, M., Pfister, S., Vince, F., Koehler, A., 2010. $\Lambda$ framework for assessing off-stream freshwater use in LCA. The International Journal of Life Cycle Assessment 15 (5), 439-453.

$\mathrm{BCl}$, 2012. Better Cotton Initative (online, accessed 24.03.13.) Available at: bettercotton.org/.

Berger, M., Finkbeiner, M., 2010. Water footprinting: how to address water use in life cycle assessment? Sustainability 2, 919-944.

BLFUW, 2000a. Ministry for Land and Forestry, Regulation on the Emissions limits of Waste Water from the Production of Man-Made Fibres (in German). Bundesgesetzblatt 18 th July 2000.

BLFUW, 2000b. Ministry for Land and Forestry, Regulation on the Emissions Limits of Waste Water from the Production of Bleached Pulp (in German). Bundesgesetzblatt 18 th July 2000

Cavero, J., Barros, R., Sellam, F., Topcu, S., Isidoro, D., Hartani, T., Lounis, A., 2012. APEX simulation of best irrigation and $\mathrm{N}$ management strategies for off-site $\mathrm{N}$ pollution control in three Mediterranean irrigated watersheds. Agricultural Water Management 103, 88-99.

CEOWM, 2012. Water $\Lambda$ ssessment Methods (online, accessed 24.03.13.) Available at: ceowatermandate.org/water-assessment-tools-methods/.

Chapagain, A.K., Hockstra, A.Y., Savenije, H.H.G., Gautam, R., 2006. The water footprint of cotton consumption: an assessment of the impact of worldwide consumption of cotton products on the water resources in the cotton producing countries. Ecological Economics 60.

Chico, D., Aldaya, M.M., Garrido, A., Llamas, M.R., Salmoral, G., 2010. The Water Footprint and Virtual Water Exports of Spanish Tomatoes. Papeles de Agua Virtual. Número 8. Fundación Botín, Madrid (online, accessed 24.03.13.) Available at: 
www.fundacionbotin.org/papeles-de-agua-virtual-n-8-the-water-footprint-andvirtual-water-exports-of-spanish-tomatoes pub-1773803518137678.htm.

Cotton Outlook, 2012. A- Index. Average World Prices (online, accessed 24.03.13.) Available at: www.cotlook.com.

Cucek, L., Klemes, J.J., Kravanja, Z., 2012. A Review of footprint analysis tools for monitoring impacts on sustainability. Journal of Cleaner Production 34, 9-20.

De Stefano, L., Martínez-Cortina, L., Chico, D., 2012. An overview of groundwater resources in Spain. In: De Stefano, L., Llamas, R.M. (Eds.), Water, Agriculture and the Environment in Spain: Can We Square the Circle? Ed.Fundación Botín Tailor and Francis CRC Press, 10:0415631521.

DHG, 2009. Drought Report of the Guadalquivir River Basin District August 2009 (in Spanish) (online, accessed 24.03.13.) Available at: www.chguadalquivires/ opencms/portalchg/laDemarcacion/guadalquivir/laGestionAgua/ informacionHidrologica/politicaGestionSequias/informeSequias/index.html.

DHG, 2012. Guadalquivir River Basin District, River Basin Management Plan (in Spanish). (online, accessed 10.02.13.) Available at: www.chguadalquivir.es opencms/portalchg/planHidrologicoDemarcacion/participacionPublica/ consultaPublica.

EC, 2002. Implementation of Council Directive 91/676/EEC Concerning the Protection of Waters against Pollution Caused by Nitrates from $\Lambda$ gricultural Sources. Office for Official Publications of the European Communities, Luxembourg.

EC, 2012. Working Draft Best Available Techniques (BAT)Reference Document for the Production of Pulp, Paper and Board Joint Research Center (online, accessed 24.03.13.) Available at: eippcb.jrc.es/reference/.

EC, 2013. Europena Commission, DG Agriculture and Rural Development. Glossary of terms Center (online, accessed 24.03.13.) Available at: ec.europa.eu/ agriculture/glossary/index en.htm.

Estrela, T., Quintas, L., 1996. A distributed hydrological model for water resources assessment in large basins. In: RIVERTECH 96.1st International Conference on New/Emerging Concepts for Rivers. IWRA. Sep. 22-26, 1996. Chicago. EE.UU.

FAO, 2009. CROPWAT 8.0 Model. Food and Agriculture Organization, Rome, Italy (online, accessed 24.03.13.) Available at: www.fao.org/nr/water/infores databases cropwat. html.

García-Vila, M., Lorite, I.J., Soriano, M.A., Fereres, E., 2008. Management trends and responses to water scarcity in an irrigation scheme of southern Spain. Agricultural Water Management 95 (4), 458-468.

Garrido, A., Llamas, M.R., Varela, C., Novo, P., Rodríguez Casado, R., Nldaya, M.M., 2010. Water Footprint and Virtual Water Trade: Policy Implications. Observatorio del Agua, Fundación Marcelino Botín, Santander.

Giannoccaro, G., Berbel, J., 2011. Influence of the common agricultural policy on the Farmer's intended decision on water Use. Spanish Journal of Agricultural Research 9 (4), 1021-1034.

Granado, R., San Miguel, P., Garcia, R., Polonio, D., 2008. Impact of the reforms of the cotton support scheme in Andalusia. In: Proceedings of International Cotton Conference on Rationales and Evolution of Cotton Policies. Pg. 38-49. May 1317, 2008. Montpellier (France).

Herath, I., Green, S., Horne, D., Singh, R., Mclaren, S., Clothier, B., 2013d. Water footprinting of agricultural products: evaluation of different protocols using a case study of New Zealand wine. Journal of Cleaner Production 44, 159-167.

Herath, L., Green, S., Singh, R., Horne, D., van der Zijpp, S., Clothier, B., 2013b. Water footprinting of agricultural products: a hydrological assessment for the water footprint of New Zealand's wines. Journal of Cleaner Production 41, 232-243.

Hockstra, A.Y., Chapagain, A.K., Mldaya, M.M., Mekonnen, M.M., 2011. The Water Footprint Assessment Manual: Setting the Global Standard. Farthscan, Iondon, UK.

Hoekstra, A.Y., Mekonnen, M.M., Chapagain, A.K., Mathews, R.F., Richter, B.D., 2012 Global monthly water scarcity: blue water footprints versus blue water availability. Plos One 7 (2)

Hurtado, M.D., Andreu, L., Abril, J.M., Delgado, A., 2011. Nitrate loss from a tiledrained reclaimed marsh soil from $S W$ Spain amended with different products. Nutrient Cycling in Agroecosystems 91 (3), 255-267.

IA, 2005. Diagnosis of the Andalusian Cotton Sector. Andalusian Regional Government, Publications of the Agricultural and Fishing Office (in Spanish). (online, accessed 24.03.13.) Available at: www.juntadeandalucia.es/servicios/ publicaciones/detalle/43139.html.

JA, 2007. Impact of the Application of the Reform of Agricultural Subsidies System in the Cotton Producing and Ginning Sectors. Andalusian Regional Government, Publications of the Agricultural and Fishing Office (in Spanish) (online, accessed 24.03.13.) Available at: www.juntadeandalucia.cs/agriculturaypesca/portal/ servicios/estadisticas/estudios-e-informes/agricultura/herbaceos-extensivos/sectoralgodonero/impacto-de-la-reforma-del-regimen-al-sector-productor-ydesmotador-del-algodon.html.

IA, 2008. Cotton Production Fstimation in Andalusia in the 2008/09 Cropping Season. Andalusian Regional Government, Publications of the $\Lambda$ gricultural and Fishing Office (in Spanish) (online, accessed 24.03.13.) Available at: www.juntadeandalucia. es/agriculturaypesca/portal/export/sites/default/comun/galerias/galeriaDescargas/ cap/agricultura-ganaderia/algodon noviembre08.pdf.

JA, 2010. Regional Irrigation Systems Inventory, 2008 and Their Evolution in the Last Decade. Andalusian Regional Government, Publications of the Agricultural and Fishing Office (in Spanish) (online, accessed 24.03.13.) Available at: www. juntadeandalucia.es/agriculturaypesca/portal/areas-tematicas/infraestructurasagrarias/regadios-e-infraestructuras-agrarias/sig-de-regadios/evolucion.html.

Jefferies, D., Muñoz, I. Hodges, J., King, V.J., Aldaya, M.M., Ercin, A.E., Milà i Canals, Ll., Hoekstra, A.Y., 2012. Water footprint and life cycle assessment as approaches to assess potential impacts of products on water consumption. Key leaming points from pilot studies on tea and margarine. Journal of Cleaner Production, 155-166.

Jeswani, H.K., Azapagic, A., 2011. Water footprint: methodologies and a case study for assessing the impacts of water use. Journal of Cleaner Production 19, 1288-1299.

Jewitt, G., 2006. Integrating blue and green water flows for water resources management and planning. Physics and Chemistry of the Earth 31 (15-16), 753-762.

Koehler, $\Lambda$., 2008. Water use in LCA: managing the planet's freshwater resources. The International Journal of Life Cycle Assessment 13 (6), 451-455.

Iópez. Bellido, I, 2003. In: Cultivos Industriales. Mundi-Prensa, Madrid.

Lorite, IJ., García-Vila, M., Carmona, M.A., Santos, C., Soriano, M.A., 2012. Assessment of the irrigation advisory services' recommendations and farmers' irrigation management: a case study in southern Spain. Water Resources Management 26 (8), 2397-2419.

MAGRAMA, 2009. Report on Hydrological Year 2004-2005. Spanish Ministry of Agriculture, Food and the Environment (in Spanish) (online, accessed 24.03.13.) Available at: www.magrama.gob.es/es/agua/temas/observatorio-nacional-dela-sequia/anual 20042005 tcm7-197594.pdf.

MAGRAMA, 2012. Food and Agriculture Statistics Yearbook. Spanish Ministry of Agriculture, Food and the Environment (in Spanish) (online, accessed 24.03.13.) Available at: www.mapa.es/es/estadistica/pags/anuario/introduccion.htm.

Mekonnen, M.M., Hoekstra, A.Y., 2010. The Green, Blue and Grey Water Footprint of Crops and Derived Crop Products. Value of Water Research Report Series UNESCO-IHE 1, 47.

Milà i Canals, L., Chenoweth, J., Chapagain, A., Orr, S., Antón, A., Clift, R., 2009. Assessing freshwater use impacts in LCA: Part I - inventory modelling and characterisation factors for the main impact pathways. The International Journal of Life Cycle Assessment 14 (1) 28-42.

Montesinos, P., Camacho, E., Campos, B., Rodríguez-Diaz, J.A., 2011. Analysis of virtual irrigation water. Application to water resources management in a Mediterranean river basin. Water Resources Management 25 (6), 1635-1651.

Muthu, S.S., Li, Y., Hu, J.Y., Mok, P.Y, 2012. Quantification of environmental impact and ecological sustainability for textile fibres. Fcological Indicators 13 (1), 66-74.

Page, G., Ridoutt, B., Bellotti, B., 2012. Carbon and water footprint tradeoffs in fresh tomato production. Journal of Cleaner Production 32, 219-226.

Pfister, S., Kochler, $\Lambda$. Hellweg, S., 2009. Assessing the envirommental impacts of freshwater consumption in ICA. Environmental Science \& Technology 43 (11) $4098-4104$.

Ridoutt, B.G., Pfister, S., 2012. A new water footprint calculation method integrating consumptive and degradative water use into a single stand-alone weighted indicator. The International Journal of Life Cycle Assessment 18, 204-207.

Ridoutt, B.G., Sanguansri, P., Nolan, M., Marks, N., 2011. Meat consumption and water scarcity: beware of generalizations. Journal of Cleaner Production 28, 1-7.

Rijsberman, F.R., 2006. Water scarcity: fact or fiction. Agricultural Water Management 80, 5-22.

SAC, Sustainable Apparel Coalition, 2012. (online, accessed 24.03.13) Available at: www.apparelcoalition.org/.

SAIH, 2012. Hydrological Information System. Andalusian Water Agency (in Spanish) (online, accessed 24.03.13.) Available at: www.juntadeandalucia.es agenciadelagua/saih/DatosHistoricos.aspx.

Salmoral, G., Dumont, A., Aldaya, M.M., Llamas, M.R., 2011a. The Water Footprint of the Guadalquivir River Basin. In: Water and Food Security and Care of Nature Case Study Publications, vol. 11. Fundación Botín, Madrid (in Spanish) (online, accessed 24.03.13.) Available at: www.fundacionbotin.org/file/38761.

Salmoral, G., Aldaya, M.M., Chico, D., Garrido, A., Llamas, M.R., 2011b. The water footprint of olives and olive oil in Spain. Spanish Journal of Agricultural Research 9(4)

Santos, C., Lorite, I.J., Tasumi, M., Allen, R.G., Fereres, E., 2010. Performance assessment of an irrigation scheme using indicators determined with remote sensing techniques. Irrigation Science 28 (6), 461-477.

Schornagel, J., Niele, F., Worrell, E., Böggemann, M., 2012. Water accounting for (agro)industrial operations and its application to energy pathways. Resources, Conservation and Recycling 61, 1-15.

Shen, L., Worrell, E., Patel, M., 2010. Environmental impact assessment of manmade cellulose fibres. Resources, Conservation and Recycling 55 (2), 260-274.

SIAR Irrigation Advisory Service, 2012. Andalusian Regional Govermment, Agricultural and Fishing Office (online, accessed 24.03.13.) Available at: www. juntadeandalucia.es/agriculturaypesca/ifapa/ria/servlet/FrontController.

UNEP/SETAC The life Cycle Initiative. (online, accessed 24.03.13) Available at: lcinitiative.unep.fr/.

UNEP, 2011. Water Footprint and Corporate Water Accounting for Resource Efficiency. Kulper, D., Zarate, E., Aldayd, M.M., Morrison, J., Schulte, P., Schenck R. Publications from Sustainable Consumption and Production Branch. (online, accessed 24.03.13.) Available at: www.unep.fr/scp/publications/details.asp? id $\mathrm{DTI} / 1411 / \mathrm{PA}$.

van Oel, P.R., Hoekstra, A.Y., 2012. Towards quantification of the water footprint of paper: a first estimate of its consumptive component. Water Resources Management 26 (3), 733-749.

Velthof, G.I., Oudendag, D.A., Oenema, O., 2007. Development and Application of the lntegrated Nitrogen Model. Alterrd Report 1663.1 Alterra, Wageningen.

Willaarts, B.A., Volk, M., Aguilera, P., 2012. Assessing the ecosystem services supplied by freshwater flows in Mediterranean agroecosystems. Agricultural Water Management 105, 21-31.

Zonderland-Thomassen, M.A., Ledgard, S.F., 2012. Water footprinting - a comparison of methods using New Zealand dairy farming as a case study. Agricultural Systems $110,30-40$. 